\title{
Faktor-Faktor Yang Mempengaruhi Niat UMKM di Kota Padang Menggunakan e-Payment sebagai Metode Pembayaran
}

\author{
Lidya Namira \\ Universitas Andalas \\ lidyanamira1995@gmail.com
}

*Corresponding Author

Submitted: 99/xxx/9999 (mohon tidak diisi oleh author, bagian ini diisi oleh editor)

Accepted: 99/xxx/9999

Published: 99/xxx/9999

\begin{abstract}
Technological developments are experiencing rapid progress which will provide convenience in accessing information and in managing resources effectively and efficiently. This development has also spawned innovations, especially in financial technology that can facilitate public access to financial services, one of which is e-Payment. This study aims to obtain empirical evidence regarding the effect of perceived benefits, perceived ease of use and perceived risk on MSME's intention to use e-Payment as a Payment Method. This study uses a theory, namely The Theory Acceptance Model (TAM) which is modified by adding a risk perception variable. The data used in this study are primary data obtained from online questionnaires distributed to 95 MSMEs throughout the city of Padang which were selected using the non-probability sampling method with the Slovin formula. The data analysis technique used is SEM (Structural Equation Model) using SmartPLS 3.0 software. From the results of this study indicate that of all the constructs that have been tested, namely the perception of benefits, ease of use and risk affect the intention of MSMEs in using e-Payment as a payment method. In this study, the TAM theory coupled with risk perception has proven that the independent variable in this study can explain its influence on the behavioral intention variable by $48.5 \%$ on the intention variable.
\end{abstract}

Keywords: Perceived Usefullness, Perceived Ease of Use, Perceived Risk, Intention, SMEs

\section{PENDAHULUAN}

Perkembangan teknologi saat ini bukan merupakan hal asing bagi masyarakat Indonesia. Perkembangan teknologi mengalami kemajuan yang pesat yang akan memberikan kemudahan dalam mengakses suatu informasi serta kemudahan dalam mengelola sumber daya secara efektif dan efisien. Pertumbuhan internet juga turut serta mempengaruhi kehidupan masyarakat, kehidupan yang dekat dengan gadget dan internet. Pertumbuhan internet juga melahirkan inovasiinovasi khususnya dalam teknologi keuangan (financial technology) yang dapat mempermudah akses masyarakat terhadap layana keuangan (Rahma, 2018). Pertumbuhan internet juga telah membuka konektivitas untuk sektor usaha mikro, kecil dan menengah (UMKM) yang memainkan peran vital dalam perekonomian (Martawardaya, 2020). Perkembangan teknologi yang terjadi dapat membuka peluang pasar yang lebih luas bagi pelaku UMKM.

UMKM saat ini memiliki peran yang penting dalam perekonomian Indonesia, karena 99,99\% bentuk usaha di Indonesia adalah berupa UMKM (Kemenkop, 2012). UMKM berkembang sangat cepat (Suci, 2017) dalam kurun waktu belakangan ini. Berbagai bentuk UMKM tumbuh dengan sendirinya tanpa perlu bimbingan dari suatu lembaga. Fasilitas serta ilmu untuk menjalakan UMKM dapat ditemukan pada berbagai sarana. Pemanfaatan teknologi menjadi tantangan tersendiri bagi UMKM untuk dapat bertahan pada era saat ini. Fungsi utama dari pemanfaatan teknologi adalah untuk dapat memudahkan setiap transaksi yang dilakukan. 
Sayangnya di Indonesia, kemudahan ini kurang dimanfaatkan oleh pelaku bisnis serta pelanggannya. Sebuah penelitian tentang permasalahan UMKM menyebutkan bahwa permasalahan penggunaan serta pemanfaatan teknologi masih menjadi masalah utama bagi UMKM (Maier, 2016).

Fintech merupakan akronim dari financial technology, sebuah bentuk inovasi layanan keuangan berbasis teknologi. Fintech memiliki berbagai bentuk layanan seperti payment fintech, capital market fintech, crowdfunding fintech, Peer to Peer. Berbagai solusi yang ditawarkan oleh fintech sudah mulai menjadi tren di dunia seiring dengan perkembangan teknologi. Bentuk fintech yang paling populer di berbagai negara maju yaitu crowfunding, bentuk ini menawarkan solusi simpan pinjam kepada penggunanya. Pemberi pinjaman dapat berasal dari masyarakat yang memiliki uang lebih dalam jumlah berapapun, serta peminjam dapat berasal dari masyarakat manapun serta dalam jumlah berapapun. Hal ini menghapuskan beberapa syarat-syarat dan birokrasi yang pada awalnya ada pada institusi sebelumnya dengan tetap diawasi oleh pemerintah. Selain bentuk crowfunding ada bentuk lain yang berkembang di berbagai Negara adalah pembayaran secara elektronik (e-payment), e-payment merupakan layanan pembayaran cashless yang bertujuan mengurangi kesalahan dalam bertransaksi (Junadi \& Sfenrianto, 2015). Di Indonesia penggunaan e-payment ini sudah diterapkan dalam pembayaran jalan tol, serta pembayaran di berbagai gerai modern. Berbagai keuntungan telah diperoleh penerapan e-payment di Indonesia, seperti masyarakat merasa aman untuk melakukan transaksi, kemudahan bertransaksi, mudah dipelajari, serta perasaan menyenangkan saat menggunakan e-payment (Junadi, 2015).

Dewasa ini di Indonesia terdapat 359 perusahaan, 24 lembaga keuangan, dan 19 mitra asosiasi yang terdaftar sebagai anggota dari AFTECH. Sedangkan terdapat 131 perusahaan yang telaha berizin dan terdaftar di Otoritas Jasa Keuangan (OJK) per tanggal 24 Mei 2021. Jumlah perusahaan yang menyelenggarakan Fintech masih terus bertambah setiap tahunnya, hal ini terbukti dari data yang diunggah oleh OJK bahwasannya jumlah perusahaan Fintech baik yang sudah terdaftar atau yang masih proses pendaftaran masih terus mengalami peningkatan. Hal ini merupakan suatu hal yang positif karena dengan semakin banyak perusahaan yang mempunyai izin operasional di harapkan dapat memberikan kenyamanan kepada masyarakat dalam menggunakan jasa layanan keuangan berbasis teknologi digital. Dalam hal ini pihak yang berwenang dalam mengatur operasional Fintech adalah Bank Indonesia (BI), Otoritas Jasa Keuangan (OJK), dan Kementrian Komunikasi dan Informasi (KEMKOMINFO). Regulasi dari pihak berwenang sangat bermanfaat bagi konsumen sehingga hak-hak konsumen dapat terlindungi sehingga konsumen mendapat kenyamanan saat bertransaksi.

Industri e-payment di Indonesia saat ini telah berkembang dan banyak bermunculan perusahaan penyedia layanan e-payment yang ikut meramaikan persaingan pasar, serta ada beberapa bank yang menjalin kerja sama dengan pengembang dan menciptakan produk baru. Bahkan ada perusahaan yang mendirikan anak perusahaan guna bersaing dengan model bisnis baru pada industri e-payment. Di Indonesia produk e-payment antara lain Go-Pay, OVO, ShopeePay, DANA, Kredivo, dan sebagainya.

Dengan berbagai fakta di atas, maka sangat mungkin bagi e-payment untuk berkembang di Indonesia. Bahkan di Indonesia, e-payment menjadi solusi yang sudah diawasi oleh pemerintah melalui lembaga Bank Indonesia (BI) dan Otoritas Jasa Keuangan (OJK). Sayangnya, penyerapan jasa ini masih kurang di Indonesia. UMKM mewakili $98 \%$ porsi pengusaha yang belum terlayani secara finansial. Padahal masyarakat di dunia menganggap layanan teknologi berbasis teknologi yang sedang berkembang dapat menjadi alternatif pada layanan finansial sejak layanan konvensional banyak mengalami permasalahan dan skandal pada krisis ekonomi tahun 2008 (Gelis \& Woods, 2014)

Abrahão et al (2016) meneliti tentang adopsi pembayaran secara mobile menggunakan Unified Theory of Acceptance and Use of Technology (UTAUT) di Brazil. Mereka melakukan survey terhadap pengguna dari suatu operator di Brazil yang berpotensi menggunakan pembayaran secara mobile dengan berbagai tipenya (prabayar, pascabayar, dan lain-lain). Metode sampling digunakan secara non-probabilistik karena kemudahan mengakses data dari operator di atas. Permasalahan yang ditemukan pada penelitian di atas adalah kurangnya sumber daya 
teknologi yang meliputi traditional phone dan smartphone di Brazil. Hal lain yang menyebabkan kurangnya adopsi adalah peraturan yang belum selesai terdefinisikan di Brazil (Abrahão et al., 2016).

Leong et al (2017) meneliti tentang tipe pengguna fintech yang berupa layanan pinjaman di Cina. Mereka melakukan penelitian tentang fenomena perilaku dan sifat peminjam secara kualitatif yang hasilnya dapat digunakan oleh perusahaan rintisan untuk mengambil kesimpulan agar layanannya dapat berhasil secara bisnis. Hasil yang didapatkan adalah suatu perusahaan fintech di Cina dapat melejit bisnisnya karena mereka menawarkan pinjaman terhadap peminjam yang berasal dari kalangan mahasiswa. Mahasiswa mau meminjam karena kebanyakan dari mereka tidak dapat melakukan pinjaman kepada bank karena tidak bankable. Pada awalnya, mahasiswa banyak melakukan pinjaman untuk kebutuhan tersier mereka seperti membeli smartphone dan laptop. Hal ini dirasakan beresiko tinggi terhadap pemberi pinjaman karena barang tersebut turun harganya serta bukan merupakan kebutuhan bisnis yang terlalu penting. Untuk mengurangi resiko tersebut, perusahaan fintech di atas mengeluarkan produk fintech lain yang berupa investasi serta perdagangan agar peminjam yang kebanyakan berasal dari mahasiswa tetap dapat menstabilkan kondisi keuangannya (Leong et al., 2017).

Technology Acceptance Model (TAM) adalah salah satu teori perilaku yang menjelaskan tentang model pendekatan penerimaan teknologi. TAM ini dikemukakan oleh Davis (1989)setidaknya ada tiga faktor yang mempengaruhi pengguna dalam menggunakan suatu teknologi baru yaitu manfaat atau perceived usefulness (dimana pengguna yakin bahwa dengan menggunakan sistem ini akan meningkatkan kinerjanya), kemudahan penggunaan atau perceived ease of use (pengguna yakin bahwa menggunakan sistem ini akan membuat pengguna mudah dalam penggunaannya) dan niat menggunakan teknologi atau intention to use yang merupakan suatu keinginan (niat) seseorang untuk melakukan suatu perilaku tertentu. Alasan penggunaan teori TAM dalam penelitian ini adalah karena kesederhanaan dan kemampuan menjelaskan hubungan sebab akibat. Tujuan dari TAM adalah untuk menyediakan penjelasan secara umum mengenai faktor determinan minat seseorang untuk menggunakan teknologi dan TAM diharapkan mampu menjelaskan perilaku pengguna akhir (end user). Penelitian ini akan melihat bagaimana tiga faktor yang mempengaruhi minat pengguna dalam menggunakan e-payment pada sektor UMKM di kota Padang dan sekitarnya

\section{STUDI LITERATUR}

\section{Pengaruh Persepsi Manfaat terhadap Minat UMKM Menggunakan e-Payment Sebagai Metode Pembayaran}

Persepsi manfaat (Perceived usefulness) didefinisikan sebagai tingkat dimana seseorang percaya bahwa menggunakan sistem tertentu dapat meningkatkan kinerja pekerjaannya (Jogiyanto, 2007). Hal ini juga didukung oleh Davis (1989) yang menyebutkan bahwa persepsi manfaat merupakan tingkat keyakinan seseorang bahwa bila menggunakan suatu teknologi maka akan meningkatkan kinerja pekerjaan dalam dirinya. Semakin meningkat keefektifan suatu media semakin meningkat pula tingkat persepsi manfaatnya. Wibowo (2008) menjelaskan bahwa dimensi tentang kemanfaatan teknologi informasi meliputi manfaat dan efektivitas. Dimensi manfaat yaitu menjadikan pekerjaan lebih mudah, bermanfaat, dan menambah produktivitas. Sedangkan dimensi efektivitas, meliputi mempertinggi efektivitas, dan mengembangkan kinerja pekerjaan. Dari beberapa definisi tersebut, dapat disimpulkan bahwa seseorang akan memanfaatkan suatu teknologi apabila teknologi tersebut bermanfaat bagi dirinya serta dapat meningkatkan kinerjanya sehingga dapat menambah produktivitas. Beberapa penelitian terdahulu telah menunjukkan bahwa persepsi manfaat berpengaruh positif terhadap minat menggunakan $e$ payment, diantaranya yaitu Candraditya dan Idris (2013), Khatimah dan Halim (2014), Miliani dan Indriani (2013), dan Rahmatsyah (2011). Dengan kata lain, Persepsi manfaat berpengaruh besar terhadap minat, karena dianggap paling mampu menjelaskan manfaat dari minat menggunakan e-payment ini. Individu berpendapat bahwa manfaat yang diperoleh dari penggunaan minat menggunakan e-payment dapat memberikan kemudahan dan kecepatan dalam 
melakukan transaksi pembayaran. Berdasarkan uraian tersebut, maka peneliti merumuskan hipotesis alternatif sebagai berikut:

H1: Persepsi Manfaat berpengaruh Terhadap Minat UMKM Menggunakan e-Payment Sebagai Metode Pembayaran

\section{Pengaruh Persepsi Kemudahan Penggunaan terhadap Minat UMKM Menggunakan $e$ -} Payment Sebagai Metode Pembayaran

Persepsi kemudahan penggunaan (perceived ease of use) didefinisikan sebagai tingkat dimana seseorang percaya bahwa menggunakan suatu teknologi akan bebas dari usaha (Jogiyanto, 2007). Hal ini juga didukung oleh Davis (1989) yang menyatakan bahwa persepsi kemudahan penggunaan sebagai tingkat dimana seseorang meyakini bahwa penggunaan teknologi informasi merupakan hal yang mudah dan tidak memerlukan usaha keras dari pemakainya. Persepsi individu berkaitan dengan kemudahan penggunaan (perceived ease of use) merupakan tingkat dimana individu percaya bahwa menggunakan sistem tertentu akan bebas dari kesalahan. Beberapa penelitian terdahulu telah menunjukkan bahwa persepsi kemudahan penggunaan berpengaruh positif terhadap minat menggunakan minat menggunakan e-payment, diantaranya yaitu Khatimah dan Halim (2014) dan Rahmatsyah (2011). Hasil ini sesuai dengan manfaat yang diberikan minat menggunakan e-payment kepada para konsumen selaku pengguna minat menggunakan e-payment yaitu berupa penggunaan uang elektronik yang sangat mudah digunakan, mudah dipahami, praktis, dan fleksibel. Berdasarkan uraian tersebut, maka peneliti merumuskan hipotesis alternatif sebagai berikut:

H2: Persepsi kemudahan penggunaan berpengaruh terhadap Minat UMKM Menggunakan e-Payment Sebagai Metode Pembayaran

\section{Pengaruh Persepsi Risiko terhadap Minat UMKM Menggunakan e-Payment Sebagai Metode Pembayaran}

Persepsi risiko dipandang sebagai ketidakpastian yang dihubungkan dengan hasil dari suatu keputusan (Sitkin dan Pablo, 1992). Risiko adalah suatu keadaan ketidakpastian yang dipertimbangkan individu untuk memutuskan atau tidak menggunakan uang elektronik. Menurut Sjöberg, Moen, dan Rundmo (2004), persepsi risiko merupakan penaksiran subyektif mengenai kemungkinan akan timbulnya suatu kecelakaan dan bagaimana kekhawatiran akan konsekuensi yang ditimbulkan. Persepsi risiko mencangkup evaluasi kemungkinan atas konsekuensi dari akibat yang negatif. Persepsi risiko mengarah pada kepercayaan keyakinan mengenai kemungkinan keuntungan ataupun kerugian diluar pertimbangan bahwa meliputi hubungan dengan kepercayaan secara khusus. Dalam penelitian ini indikator risiko dilihat dari tindakan yang dilakukan oleh bank untuk memperkecil risiko dari penggunaan uang elektronik, diharapkan tindakan yang dilakukan oleh bank untuk memperkecil risiko akan berdampak positif pada minat konsumen selaku pengguna fasilitas uang elektronik yang ditawarkan. Beberapa penelitian terdahulu telah menunjukkan bahwa persepsi risiko berpengaruh positif terhadap minat menggunakan minat menggunakan e-payment, diantaranya yaitu Jarvenpaa dan Staples (2000) dan Miliani dan Indriani (2013)Namun terdapat penelitian dengan hasil bahwa persepsi risiko berpengaruh negatif terhadap minat menggunakan minat menggunakan e-payment yaitu Gurung (2006). Berdasarkan uraian tersebut, maka peneliti merumuskan hipotesis alternatif sebagai berikut:

H3: Persepsi risiko berpengaruh terhadap Minat UMKM Menggunakan e-Payment Sebagai Metode Pembayaran

Populasi dan Sampel

METODE

Populasi pada penelitian ini adalah seluruh pelaku Usaha Mikro, Kecil dan Menengah berdasarkan data Dinas Koperasi dan UMKM Kota Padang. Jumlah populasi 
pada penelitian ini adalah 2.062 UMKM. Penelitian ini akan menggunakan teknik sampling Non-probability Sampling dengan menggunakan rumus slovin. Sampel pada penelitian ini ditentukan dengan menggunakan rumus Slovin:

Keterangan:

$$
\begin{gathered}
n=\frac{N}{1+N e^{2}} \\
n=\frac{2.062}{\left(1+\left(2.062 \times 0.1^{2}\right)\right)} \\
n=95,37 \approx 95 \text { orang }
\end{gathered}
$$

$\mathrm{n} \quad=$ Jumlah Sampel

$\mathrm{N}=$ Ukuran Populasi

$e \quad=$ Tingkat error $(10 \%)$ responden.

Berdasarkan perhitungan rumus slovin, sampel penelitian ini berjumlah 95

\section{Teknik Pengumpulan Data}

Metode pengumpulan data dilakukan melalui pembuatan kuesioner yang dibuat secara online menggunakan google form dan manual sehingga mempermudah dalam penyebarannya ke responden. Kuesioner terdiri dari dua bagian, yaitu:

1. Bagian pertama ialah pertanyaan mengenai data pribadi responden yang akan dijaga kerahasiannya.

2. Bagian kedua ialah beberapa indikator untuk menguji variabel penelitian dengan skala Likert.

Model skala likert adalah skala penilaian untuk mengukur pendapat, persepsi, atau sikap seseorang atau sekelompok orang dengan memberikan rentang nilai. Skala ini sering digunakan pada jenis penelitian berupa survey. Jawaban yang diberikan pada setiap indicator dari 1 dengan tanggapan Sangat Tidak Setuju (STS) sampai 5 dengan tanggapan Sangat Setuju (SS).

\section{Identifikasi dan Definisi Operasional Variabel}

Variabel dependen dari penelitian ini ialah minat UMKM menggunakan e-Payment. Minat UMKM menggunakan e-Payment diartikan sebagai tingkat keinginan untuk menggunakan e-Payment dengan asumsi UMKM memilki akses terhadap informasi tersebut. Sedangkan variabel independen dalam penelitian adalah Persepsi Manfaat, Persepsi Kemudahan Penggunaan

\begin{tabular}{|c|c|}
\hline Variabel & Indikator \\
\hline $\begin{array}{l}\text { Niat Penggunaan }(\mathrm{Y}) \\
\text { (Venkatesh dan Davis, } \\
\text { 1996) }\end{array}$ & $\begin{array}{l}\text { 1. Saya berniat untuk menggunakan layanan e-Payment atau pembayaran } \\
\text { elektronik sebagai alat pembayaran di masa yang akan datang. } \\
\text { 2. Saya akan selalu berusaha menggunakan layanan e-Payment atau } \\
\text { pembayaran elektronik sebagai alat pembayaran di keseharian saya. } \\
\text { 3. Saya tidak akan menghubungkan akun bank saya dengan layanan layanan } e \text { - } \\
\text { Payment atau pembayaran elektronik dalam transaksi sehari-hari. } \\
\text { 4. Saya akan mengajak orang lain untuk menggunakan layanan layanan } e \text { - } \\
\text { Payment atau pembayaran elektronik sebagai alat pembayaran. } \\
\text { 5. Menurut saya, layanan } e \text {-Payment atau pembayaran elektronik sebagai alat } \\
\text { pembayaran belum layak untuk digunakan }\end{array}$ \\
\hline $\begin{array}{l}\text { Persepsi Manfaat (X1) } \\
\text { (Phonthanukitithaworn, } \\
\text { et al, 2016) }\end{array}$ & $\begin{array}{l}\text { 1. Saya percaya bahwa menggunakan layanan layanan e-Payment atau } \\
\text { pembayaran elektronik sebagai alat pembayaran akan memungkinkan saya } \\
\text { untuk membayar lebih cepat. }\end{array}$ \\
\hline
\end{tabular}
dan Persepsi Risiko. Indikator dari masing-masing variabel tersaji pada tabel dibawah ini:

\section{Tabel 1. Indikator Variabel}


Owner: Riset \& Jurnal Akuntansi

e-ISSN : 2548-9224 | p-ISSN : 2548-7507

Volume 6 Nomor 1, Januari 2022

\begin{tabular}{|c|c|}
\hline & $\begin{array}{l}\text { 2. Saya percaya bahwa menggunakan layanan layanan e-Payment atau } \\
\text { pembayaran elektronik sebagai alat pembayaran akan meningkatkan } \\
\text { efektivitas pembayaran saya (misal: menggunakan layanan layanan e- } \\
\text { Payment atau pembayaran elektronik sebagai alat pembayaran akan } \\
\text { memungkinkan saya melakukan transaksi pembayaran kapan pun saya } \\
\text { mau). } \\
\text { 3. Saya percaya bahwa menggunakan layanan layanan e-Payment atau } \\
\text { pembayaran elektronik sebagai alat pembayaran akan memudahkan saya } \\
\text { melakukan transaksi pembayaran }\end{array}$ \\
\hline $\begin{array}{l}\text { Persepsi Kemudahaan } \\
\text { Penggunaan (X2) } \\
\text { (Phonthanukitithaworn, } \\
\text { et al, 2016) }\end{array}$ & $\begin{array}{l}\text { 1. Saya percaya bahwa layanan layanan e-Payment atau pembayaran } \\
\text { elektronik sebagai alat pembayaran mudah digunakan. } \\
\text { 2. Saya percaya bahwa saya akan mudah menemukan cara menggunakan } \\
\text { layanan layanan e-Payment atau pembayaran elektronik sebagai alat } \\
\text { pembayaran. }\end{array}$ \\
\hline $\begin{array}{l}\text { Persepsi Risiko (X3) } \\
\text { (Utami, 2016) }\end{array}$ & $\begin{array}{l}\text { 1. Saya khawatir apabila layanan layanan e-Payment atau pembayaran } \\
\text { elektronik sebagai alat pembayaran yang saya gunakan tidak dapat } \\
\text { difungsikan dengan baik. } \\
\text { 2. Saya merasa tidak aman ketika bertransaksi menggunakan layanan layanan } \\
\text { e-Payment atau pembayaran elektronik sebagai alat pembayaran. } \\
\text { 3. Saya menemukan banyak risiko ketika melakukan transaksi menggunakan } \\
\text { layanan layanan e-Payment atau pembayaran elektronik sebagai alat } \\
\text { pembayaran. }\end{array}$ \\
\hline
\end{tabular}

\section{Teknik Analisa Data}

Penelitian ini menggunakan analisis regresi partial (Partial Keast Square/ PLS) untuk menguji ketiga hipotesis yang diajukan dalam penelitian ini. Masing-masing hipotesis akan dianalisis menggunakan software SmartPLS 3.0 untuk menguji hubungan antar variable.

\section{Uji Validitas}

\section{HASIL}

Uji validitas bertujuan untuk mengukur sejauh mana variabel yang digunakan benarbenar mengukur apa yang seharusnya diukur. Pengujian validitas yang digunakan dalam penelitian ini adalah convergency validity dan discriminant validity.

1. Convergent validity

Tabel 2 di bawah ini menyajikan seluruh indikator-indikator variabel terlihat telah memenuhi syarat validitas konvergen, yakni setiap indikator $\geq 0.6$ dan average variance extracted (AVE) untuk setiap variabel $\geq 0,5$. Validitas convergent indikator reflektif akan terpenuhi jika nilai outer loadings $\geq 0.6$ untuk setiap indikator dan nilai average variance extracted (AVE) $\geq 0.5$ untuk setiap variabel (Ghozali \& Latan, 2015).

Tabel 2. Convergent Validity

\begin{tabular}{|c|c|c|c|c|}
\hline No & \multicolumn{2}{|l|}{ Indikator } & $\begin{array}{l}\text { Outer } \\
\text { Loadings }\end{array}$ & AVE \\
\hline \multicolumn{5}{|c|}{ Minat Menggunakan e-Payment } \\
\hline 1 & $\begin{array}{l}\text { Saya berniat untuk menggunakan layanan e-Payment } \\
\text { sebagai alat pembayaran di masa yang akan datang }\end{array}$ & MP1 & 0.827 & \multirow{5}{*}{0.714} \\
\hline 2 & $\begin{array}{l}\text { Saya akan selalu berusaha menggunakan e-Payment } \\
\text { sebagai alat pembayaran di keseharian saya }\end{array}$ & MP2 & 0.806 & \\
\hline 3 & $\begin{array}{l}\text { Saya akan menghubungkan akun bank saya dengan } \\
\text { layanan } e \text {-Payment dalam transaksi sehari-hari }\end{array}$ & MP3 & 0.876 & \\
\hline 4 & $\begin{array}{l}\text { Saya akan mengajak orang lain untuk menggunakan } \\
\text { layanan } e \text {-Payment sebagai alat pembayaran }\end{array}$ & MP4 & 0.866 & \\
\hline 5 & $\begin{array}{l}\text { Menurut saya, layanan e-Payment belum layak digunakan } \\
\text { sebagai alat pembayaran }\end{array}$ & MP5 & 0.847 & \\
\hline
\end{tabular}




\begin{tabular}{|c|c|c|c|c|}
\hline \multicolumn{5}{|c|}{ Persepsi Manfaat } \\
\hline 1 & $\begin{array}{l}\text { Saya percaya bahwa menggunakan e-Payment sebagai alat } \\
\text { pembayaran akan memungkinkan saya untuk membayar } \\
\text { lebih cepat }\end{array}$ & PM1 & 0.695 & \multirow{3}{*}{0.557} \\
\hline 2 & $\begin{array}{l}\text { Saya percaya bahwa menggunakan layanan e-Payment } \\
\text { sebagai alat pembayaran akan meningkatkan efektivitas } \\
\text { pembayaran saya (misal: menggunakan layanan e-Payment } \\
\text { sebagai alat pembayaran akan memungkinkan saya } \\
\text { melakukan transaksi pembayaran kapan pun saya mau) }\end{array}$ & PM2 & 0.720 & \\
\hline 3 & $\begin{array}{l}\text { Saya percaya bahwa menggunakan layanan e-Payment } \\
\text { sebagai alat pembayaran akan memudahkan saya } \\
\text { melakukan transaksi pembayaran }\end{array}$ & PM3 & 0.818 & \\
\hline \multicolumn{5}{|c|}{ Persepsi Kemudahan Menggunakan } \\
\hline 1 & $\begin{array}{l}\text { Saya percaya bahwa layanan e-Payment sebagai alat } \\
\text { pembayaran mudah digunakan }\end{array}$ & PKP1 & 0.915 & \multirow[b]{2}{*}{0.823} \\
\hline 2 & $\begin{array}{l}\text { Saya percaya bahwa saya akan mudah menemukan cara } \\
\text { menggunakan layanan } e \text {-Payment sebagai alat pembayaran }\end{array}$ & PKP2 & 0.899 & \\
\hline \multicolumn{5}{|c|}{ Persepsi Risiko } \\
\hline 1 & $\begin{array}{l}\text { Saya khawatir apabila layanan e-Payment sebagai alat } \\
\text { pembayaran yang saya gunakan tidak dapat difungsikan } \\
\text { dengan baik }\end{array}$ & PR1 & 0.791 & \multirow{3}{*}{0.668} \\
\hline 2 & $\begin{array}{l}\text { Saya merasa tidak aman ketika bertransaksi menggunakan } \\
\text { layanan } e \text {-Payment sebagai alat pembayaran }\end{array}$ & PR2 & 0.808 & \\
\hline 3 & $\begin{array}{l}\text { Saya menemukan banyak risiko ketika melakukan } \\
\text { transaksi menggunakan layanan e-Payment sebagai alat } \\
\text { pembayaran }\end{array}$ & PR3 & 0.853 & \\
\hline
\end{tabular}

Sumber: Data Diolah, 2021

2. Discriminant validity berhubungan dengan prinsip bahwa pengukur variabel yang berbeda seharusnya tidak berkorelasi dengan tinggi. Untuk menguji disciminant validity dengan indikator reflektif yaitu dengan melihat cross loading setiap konstuk harus $>0,70$ (Ghozali \& Latan, 2015). Hasil uji validitas diskriminan dapat dilihat pada tabel berikut.

Tabel 3 Discriminant Validity

\begin{tabular}{lcccc}
\hline & $\begin{array}{c}\text { Minat } \\
\text { Menggunakan }\end{array}$ & $\begin{array}{c}\text { Persepsi } \\
\text { Kemudahaan } \\
\text { Menggunakan }\end{array}$ & $\begin{array}{c}\text { Persepsi } \\
\text { Manfaat }\end{array}$ & $\begin{array}{c}\text { Persepsi } \\
\text { Resiko }\end{array}$ \\
\hline $\begin{array}{l}\text { Minat Menggunakan } \\
\text { Persepsi Kemudahaan }\end{array}$ & $\mathbf{0 . 8 4 5}$ & & & \\
Menggunakan & 0.560 & $\mathbf{0 . 9 0 7}$ & & \\
Persepsi Manfaat & 0.570 & 0.718 & $\mathbf{0 . 7 4 6}$ & $\mathbf{0 . 8 1 8}$ \\
Persepsi Resiko & 0.565 & 0.363 & 0.432 & \\
\hline
\end{tabular}

Sumber: Data Diolah, 2021

Tabel 3 diatas menunjukkan bahwa validitas discriminant dari model penelitian ini sudah baik, karena dari nilai akar kuadrat AVE untuk setiap konstruk lebih besar dari korelasi antar konstruk dalam model.

\section{Uji Realibilitas}

Dalam PLS, uji reliabilitas dilakukan dengan melihat composite reliability. Dapat dilihat bahwa semua variabel-variabel tersebut memiliki nilai composite reliability dan cronbach alpha $>0.6$. Hal ini berarti bahwa variabel-variabel dalam model penelitian ini telah memenuhi syarat reliabilitas. Syarat reliabilitas akan terpenuhi jika nilai composite reliability variabel lebih besar dari 0.6-0.7 (Ghozali \& Latan, 2015). Hasil nilai Composite Reliability dapat dilihat pada tabel berikut ini.

Tabel 4 Uji Realibilitas

\begin{tabular}{lcc}
\hline \multicolumn{1}{c}{ Variabel } & Composite Reliability & Cronbach Alpha \\
\hline Minat Menggunakan & 0.926 & 0.900 \\
Persepsi Kemudahaan Menggunakan & 0.903 & 0.786
\end{tabular}


Owner: Riset \& Jurnal Akuntansi

e-ISSN : 2548-9224 | p-ISSN : 2548-7507

Volume 6 Nomor 1, Januari 2022

DOI : https://doi.org/10.33395/owner.v6i1.553

$\begin{array}{lll}\text { Persepsi Manfaat } & \mathbf{0 . 7 9 0} & \mathbf{0 . 6 0 5} \\ \text { Persepsi Resiko } & \mathbf{0 . 8 5 8} & \mathbf{0 . 7 5 2}\end{array}$

\section{Evaluasi Inner Model}

Model struktural dilakukan dengan melihat nilai $\mathrm{R}_{2}$ (R-Square) variabel laten dependen dengan interpretasi yang sama dengan regresi yang merupakan uji goodness-fit model. Kemudian melihat hubungan jalur dan nilai R Square (R2) untuk melihat hasil evaluasi model structural (Ghozali \& Latan, 2015). Nilai $R 2$ bertujuan untuk mengetahui seberapa besar variabel independen memengaruhi variabel dependennya. Nilai R2 dapat dilihat pada tabel dibawah ini:

Tabel 5 Hasil Uji R Square

\begin{tabular}{lc} 
& R Square \\
\hline Niat Menggunakan e-Payment & 0.485
\end{tabular}

Sumber: Data Diolah, 2021

Berdasarkan Tabel diatas menunjukkan bahwa Nilai $R$-square variabel minat menggunakan financial technology (Y) dijelaskan sebesar 0,485. Hal ini berarti bahwa variabel minat menggunakan fintech dijelaskan oleh variabel persepsi manfaat, kemudahan menggunakan, dan risiko sebesar 48,5\%, sedangkan sebesar 51,5\% dijelaskan oleh variabel lain diluar penelitian ini.

\section{Pengujian Hipotesis}

Pengujian hipotesis pada PLS dilakukan dengan dua tahap, yakni menghitung langsung pengaruh variabel laten independen terhadap variabel laten dependen. Adapun output hasil Bootstraping PLS untuk menguji hipotesis penelitian (H1 sampai dengan H3) adalah sebagai berikut:

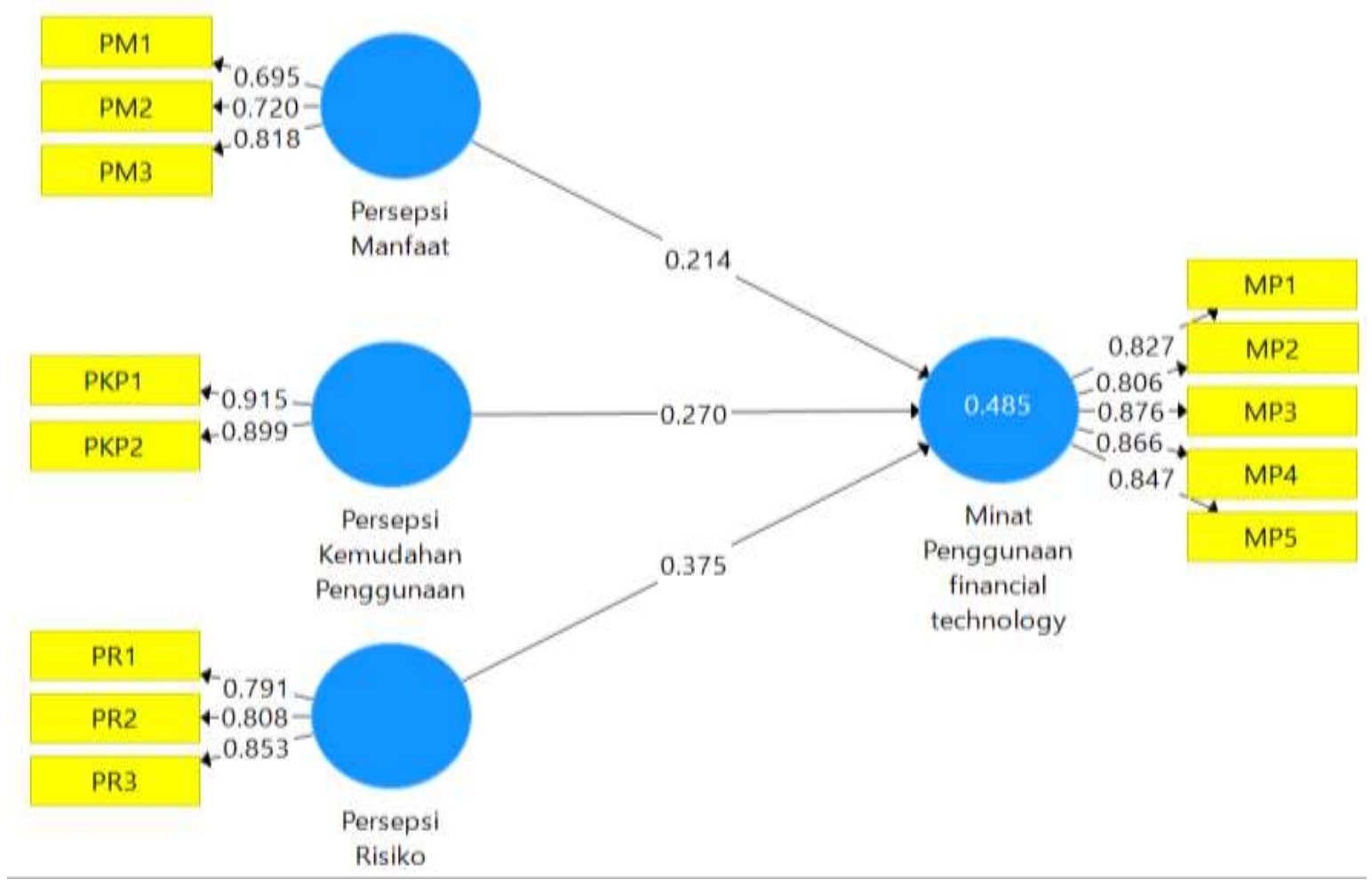

Gambar 1 Hasil Inner Model 
Pengujian selanjutnya adalah dengan melihat signifikansi pengaruh antar konstruk pada path coefficients. Hasil dari pengolahan data disajikan pada tabel berikut.

Tabel 5: Path Coefficients

\begin{tabular}{|c|c|c|c|c|c|}
\hline & $\begin{array}{l}\text { Original } \\
\text { Sample } \\
(0)\end{array}$ & $\begin{array}{l}\text { Sample } \\
\text { Mean } \\
(\mathrm{M})\end{array}$ & $\begin{array}{l}\text { Standard } \\
\text { Deviation } \\
\text { (STDEV) } \\
\end{array}$ & $\begin{array}{l}\text { T Statistics } \\
\text { (|O/STDEV|) }\end{array}$ & $\begin{array}{c}\mathbf{P} \\
\text { Values }\end{array}$ \\
\hline $\begin{array}{l}\text { Persepsi Manfaat -> Minat } \\
\text { Menggunakan } e \text {-Payment }\end{array}$ & 0.214 & 0.217 & 0.103 & 2.074 & 0.039 \\
\hline $\begin{array}{l}\text { Persepsi Kemudahan } \\
\text { Menggunakan -> Minat } \\
\text { Menggunakan } \text { e-Payment }\end{array}$ & 0.270 & 0.265 & 0.106 & 2.542 & 0.011 \\
\hline $\begin{array}{l}\text { Persepsi Risiko -> Minat } \\
\text { Menggunakan } e \text {-Payment }\end{array}$ & 0.375 & 0.385 & 0.097 & 3.851 & 0.000 \\
\hline
\end{tabular}

Sumber: Data Diolah, 2021

Hipotesis pertama menguji persepsi manfaat berpengaruh terhadap minat menggunakan e-Payment. Hasil pengujian menunjukkan nilai koefisien beta persepsi manfaat terhadap minat menggunakan e-Payment sebesar 0,214 dan t-statistik yaitu sebesar 2,074. Dari hasil ini dinyatakan t-statistik signifikan karena $>1,660(2,074>1,660)$ dengan p-value $<0,05(0,039<$ $0,05)$ sehingga hipotesis pertama diterima. Hal tersebut membuktikan bahwa persepsi manfaat terbukti memiliki pengaruh terhadap minat menggunakan e-Payment.

Hipotesis kedua persepsi kemudahan menggunakan berpengaruh terhadap minat menggunakan e-Payment. Hasil pengujian menunjukkan nilai koefisien beta persepsi kemudahan menggunakan terhadap minat menggunakan $e$-Payment sebesar 0.270 dan t-statistik yaitu sebesar 2,542. Dari hasil ini dinyatakan t-statistik signifikan karena >1,660 $(2,542>1,660)$ dengan pvalue $<0,05(0,011<0.05)$ sehingga hipotesis kedua diterima. Hal tersebut membuktikan bahwa persepsi kemudahan menggunakan terbukti memiliki pengaruh terhadap minat menggunakan e-Payment.

Hipotesis ketiga menguji persepsi risiko berpengaruh terhadap minat menggunakan e-Payment. Hasil pengujian menunjukkan nilai koefisien beta persepsi risiko terhadap minat menggunakan $e$ Payment sebesar 0,375 dan t-statistik yaitu sebesar 3,851. Dari hasil ini dinyatakan t-statistik signifikan karena > 1,660 (2,010>1,660) dengan p-value $<0,05(0.000<0.05)$ sehingga hipotesis ketiga diterima. Hal tersebut membuktikan bahwa persepsi risiko terbukti memiliki pengaruh terhadap minat menggunakan e-Payment.

\section{PEMBAHASAN}

Hubungan Persepsi Manfaat terhadap Minat Menggunakan e-Payment sebagai Alat Pembayaran

Temuan penelitian ini menunjukkan bahwa persepsi manfaat terbukti memiliki pengaruh terhadap minat menggunakan layanan e-Payment sebagai alat pembayaran. Hasil temuan ini mendukung temuan penelitian sebelumnya yang menemukan bukti bahwa persepsi manfaat berpengaruh terhadap minat menggunakan e-Payment (Candraditya dan Idris (2013), Khatimah dan Halim (2014), Miliani dan Indriani (2013), dan Rahmatsyah (2011)). Temuan penelitian ini menyiratkan bahwa persepsi manfaat merupakan tingkat keyakinan seseorang bahwa bila menggunakan suatu teknologi maka akan meningkatkan kinerja pekerjaan dalam dirinya. Semakin meningkat keefektifan suatu media semakin meningkat pula tingkat persepsi manfaatnya (Davis, 1989).

Dengan kata lain, Persepsi manfaat berpengaruh besar terhadap minat, karena dianggap paling mampu menjelaskan manfaat dari minat menggunakan e-Payment ini. Individu berpendapat bahwa manfaat yang diperoleh dari menggunakan minat menggunakan e-Payment dapat memberikan kemudahan dan kecepatan dalam melakukan transaksi pembayaran. Dugaan yang dapat dikemukakan atas temuan ini bahwa pelaku UMKM merasa dengan menggunakan 
perkembangan e-Payment dalam transaksi pembayaran memberikan manfaat bagi mereka yang dapat meningkatkan kinerja ataupun produktivitasnya.

\section{Hubungan Persepsi Kemudahan Menggunakan terhadap Minat Menggunakan e-Payment sebagai Alat Pembayaran}

Hasil penelitian ini menunjukkan bahwa persepsi kemudahan menggunakan terbukti memiliki pengaruh terhadap minat menggunakan e-Payment sebagai alat pembayaran. Hasil penelitian ini mendukung penelitian sebelumnya yang menemukan bukti bahwa persepsi kemudahaan menggunakan terhadap minat menggunakan e-Payment (Khatimah dan Halim (2014), Rahmatsyah (2011), Venkatesh dan Davis (1996)). Hasil penelitian yang dilakukan oleh (Ezeh dan Nwankwo (2018)) menemukan bahwa persepsi akan kemudahan dalam penggunaan terkait pembayaran digital berpengaruh penting terhadap niat pelanggan dalam menggunakan pembayaran digital.

Penelitian ini juga mendukung hasil penelitian yang dilakukan oleh $\mathrm{Hu}$ et al (2017), Mangeswuri et al (2018), Liu et al (2019), Marchelina dan Pratiwi (2018), dan Sitinjak (2019) yang menyatakan bahwa persepsi kemudahan penggunaan berpengaruh terhadap niat penggunaan e-payment Dugaan yang dapat dikemukakan atas temuan ini bahwa pelaku UMKM merasa dengan menggunakan perkembangan e-Payment dalam transaksi pembayaran mampu mengurangi usaha individu baik dalam waktu maupun tenaga untuk memahami dan mempelajari sistem teknologi karena individu yakin bahwa sistem teknologi mudah untuk dipelajari dan dipahami. Semakin tinggi persepsi kemudahan penggunaan dalam diri individu maka semakin tinggi minat penggunaannya, namun sebaliknya jika persepsi kemudahan penggunaan dalam diri individu rendah maka minat penggunaan $e$-wallet bagi individu pun juga rendah. Keberadaan $e$ Payment bertujuan untuk membuat UMKM lebih mudah mengakses produk-produk keuangan, mempermudah transaksi dan juga meningkatkan literasi keuangan (Mangeswuri et al., 2018).

\section{Hubungan Persepsi Risiko terhadap Minat Menggunakan Layanan e-Payment sebagai Alat Pembayaran}

Temuan penelitian ini menunjukkan bahwa persepsi risiko terbukti memiliki pengaruh terhadap minat menggunakan layanan e-Payment sebagai alat pembayaran. Temuan penelitian ini mendukung temuan Jarvenpaa et al. (2000) dan Miliani dan Indriani (2013) yang menemukan bukti persepsi risiko berpengaruh terhadap minat menggunakan layanan e-Payment sebagai alat pembayaran. Namun, temuan ini tidak sejalan dengan Gurung (2006) yang menemukan bukti bahwa bahwa persepsi risiko berpengaruh negatif terhadap minat menggunakan minat menggunakan layanan belanja elektronik. Hal ini dikarenakan dinamika perubahan sektor pemerintahan tidak diakomodasi oleh kesiapan sumber daya manusia dan tidak proaktif terhadap tekanan-tekanan publik.

Penelitian ini juga mendukung penelitian yang dilakukan Jarvenpaa dan Staples (2000)menyatakan bahwa persepsi risiko memainkan peranan yang kuat untuk mengurangi minat konsumen untuk mengambil bagian dalam e-commerce sehingga persepsi risiko dimungkinkan akan berpengaruh negatif untuk melakukan transaksi secara online. Alasan pernyataan tersebut adalah persepsi risiko hanya pembantu dalam membentuk sikap konsumen dibandingkan niat mereka. Walaupun persepsi risiko tinggi, konsumen mungkin tidak secara rela memutuskan untuk tidak mengambil bagian dalam melakukan transaksi secara online. Peneliti berpendapat bahwa Semakin besar Risiko Persepsian semakin besar pula kemungkinan keterlibatan pelaku UMKM dalam menggunakan e-Payment dalam transaksi perdagangannya.

\section{KESIMPULAN}

Penelitian ini bertujuan untuk menguji hubungan persepsi manfaat, persepsi kemudahaan penggunaan, dan persepsi risiko terhadap niat pelaku UMKM menggunakan e-Payment sebagai metode pembayaran. Penelitian ini menggunakan Technology Acceptance Model (TAM) untuk menguji niat UMKM dalam melakukan transaksi perdagangannya menggunakan $e$ - 


\section{Payment.}

Model penelitian ini diuji pada UMKM se-Kota Padang, temuan penting dalam penelitian ini adalah dari semua konstruk yang telah diuji yaitu persepsi manfaat, kemudahan penggunaan dan risiko berpengaruh terhadap niat UMKM dalam menggunakan e-Payment sebagai metode pembayaran. Pada penelitian ini teori TAM ditambah dengan persepsi risiko berhasil membuktikan bahwa variabel independen dalam penelitian ini dapat menjelaskan pengaruhnya terhadap variabel niat perilaku sebesar $48,5 \%$ terhadap variabel niat.

Berdasarkan penjelasan tersebut, dapat peneliti simpulkan bahwa layanan e-payment adalah layanan yang memberikan banyak manfaat, dapat dipercaya, aman, mudah untuk dikuasai, nyaman digunakan, dan menawarkan harga yang masuk akal. Penelitian ini memiliki beberapa keterbatasan yang dimiliki oleh peneliti dan diharapkan dapat disempurnakan pada penelitian selanjutnya. Beberapa keterbatasan yang terjadi antara lain terbatasnya responden, penelitian ini hanya 95 responden yang mana angka tersebut jumlahnya relatif kecil hal ini disebabkan karena keterbatasan waktu pengambilan data. Keterbatasan lain dari penelitian ini adalah data yang dianalisis dalam penelitian ini berdasarkan pada kuesioner persepsi jawaban responden sehingga dimungkinkan tidak mencerminkan keadaan yang sesungguhnya dan dimungkinkan ada unsur subjektif. Terakhir, penelitian ini hanya berfokus kepada persepsi manfaat, kemudahaan dan risiko tidak menggunakan seluruh variabel-variabel dari Teori TAM.

Terlepas dari berbagai keterbatasan yang ada, hasil penelitian dapat bermanfaat sebagai bahan pertimbangan bagi pelaku UMKM untuk bisa menggunakan alat pembayaran menggunakan e-Payment seperti e-Wallet, Debit Card/Credit Card, dan pembayaran elektronik lainnya yang memberi kemudahan bagi pelaku UMKM dalam menerapkan pembayaran cashless. Temuan penelitian ini dapat memberikan kontribusi bagi beberapa pihak. Pertama, bagi perusahaan, perusahaan lebih gencar memberi promosi terkait manfaat dan kemudahahan menggunakan alat pembayaran e-Paymet dalam transaksi perdagangannya sehingga perusahaan pun akan turut serta dalam mendukung program Pemerintah Gerakan Non Tunai (GTM) selain hal tersebut perusahaan juga harus memberikan perlindungan rasa aman kepada konsumen dan pelaku UMKM ketika menggunakan alat pembayaran dari perusahaan mereka, bagi pemerintah sebagai regulator melaui Bank Indoensia dan Otoritas Jasa Keuangan (OJK) harus menyusun sebuah regulasi yang mampu melindungi konsumen atau pelaku UMKM ketika menggunakan metode-metode $e$-Payment sehingga konsumen atau pelaku UMKM merasa aman ketika menggunakan metode $e$-Payment dalam bertransaksi.

Hasil penelitian ini juga diharapkan mampu memberikan kontribusi terhadap pengembangan literatur financial technology, khususnya pada bentuk financial technology e-Payment, dapat menjadi tambahan referensi dan memotivasi peneliti lain untuk pengembangan penelitian lebih lanjut dengan mempertimbangkan keterbatasanketerbatasan yang masih terdapat dalam penelitian ini. Peluang untuk penelitian berikutnya dapat dikembangkan dari penelitian ini dengan berbagai cara. Pertama, penelitian ini dapat dikembangkan dengan sampel yang lebih banyak sehingga kemampuan generalisasinya untuk memperlihatkan praktik akuntansi pemerintahan di Indonesia menjadi lebih kuat. Kedua, penelitian berikutnya dapat dilakukan dengan menambahkan variabel lain yang tidak masuk dalam model penelitian ini.

\section{REFERENSI}

Candraditya, H., \& Idris, I. (2013). Analisis penggunaan uang elektronik (Studi Kasus Pada Mahasiswa Pengguna Produk Flazz BCA di Fakultas Ekonomika dan Bisnis Universitas Diponegoro). Diponegoro Journal of Management, 97-107.

Davis, F. D. (1989). Perceived usefulness, perceived ease of use, and user acceptance of information technology. MIS Quarterly, 319-340.

de Sena Abrahão, R., Moriguchi, S. N., \& Andrade, D. F. (2016). Intention of adoption of mobile 
payment: An analysis in the light of the Unified Theory of Acceptance and Use of Technology (UTAUT). RAI Revista de Administração e Inovação, 13(3), 221-230.

Ezeh, P. C., \& Nwankwo, N. (2018). Factors that influence the acceptance of mobile money in Nigeria. Journal of Research in Marketing, 8(2), 684-697.

Gelis, P., \& Woods, T. (2014). The Rise of Fintech in Finance: How fintech is reshaping the finance sector and how you handle your money. Research Paper, Kantox.

Ghozali, I., \& Latan, H. (2015). Partial least squares konsep, teknik dan aplikasi menggunakan program smartpls 3.0 untuk penelitian empiris. Semarang: Badan Penerbit UNDIP.

Gurung, A. (2006). Empirical investigation of the relationship of privacy, security and trust with behavioral intention to transact in e-commerce. The University of Texas at Arlington.

Hu, Y., Kwon, Y., Chidambaram, V., \& Witchel, E. (2017). From crash consistency to transactions. Proceedings of the 16th Workshop on Hot Topics in Operating Systems, 100105.

Jarvenpaa, S. L., \& Staples, D. S. (2000). The use of collaborative electronic media for information sharing: an exploratory study of determinants. The Journal of Strategic Information Systems, 9(2-3), 129-154.

Jarvenpaa, S. L., Tractinsky, N., \& Vitale, M. (2000). Consumer trust in an Internet store. Information Technology and Management, 1(1), 45-71.

Jogiyanto, H. M. (2007). Sistem informasi keperilakuan. Yogyakarta: Andi Offset.

Junadi ${ }^{a}$, S. (2015). A model of factors influencing consumer's intention to use e-payment system in Indonesia. Procedia Computer Science, 59, 214-220.

Khatimah, H., \& Halim, F. (2014). The intention to use e-money transaction: The moderating effect of security in conceptual framework. American-Eurasian Journal of Sustainable Agriculture, 8(12), 41-48.

Leong, C., Tan, B., Xiao, X., Tan, F. T. C., \& Sun, Y. (2017). Nurturing a FinTech ecosystem: The case of a youth microloan startup in China. International Journal of Information Management, 37(2), 92-97.

Liu, Y., Wang, M., Huang, D., Huang, Q., Yang, H., \& Li, Z. (2019). The impact of mobility, risk, and cost on the users' intention to adopt mobile payments. Information Systems and EBusiness Management, 17(2), 319-342.

Maier, E. (2016). Supply and demand on crowdlending platforms: connecting small and mediumsized enterprise borrowers and consumer investors. Journal of Retailing and Consumer Services, 33, 143-153.

Mangeswuri, D. R., Wuryandani, D., Purwanto, N. P., Hendra, S. P., Meilani, H., Sayekti, N. W., \& Rivani, E. (2018). Industri Kreatif, Fintech dan UMKM dalam Era Digital. Jurnal Teknologi Informasi.

Marchelina, D., \& Pratiwi, R. (2018). Pengaruh persepsi manfaat, persepsi kemudahan, persepsi risiko dan fitur layanan terhadap minat penggunaan e-money (studi kasus pada pengguna e-money kota palembang).

Martawardaya, B. (2020). Teknologi Disruptif dan Peluangnya.

Miliani, L., \& Indriani, M. T. D. (2013). Adoption behavior of e-money usage. Information Management and Business Review, 5(7), 369-378.

Phonthanukitithaworn, C., Sellitto, C., \& Fong, M. W. L. (2016). An investigation of mobile payment (m-payment) services in Thailand. Asia-Pacific Journal of Business Administration.

Rahmatsyah, D. (2011). Analisa faktor-faktor yang mempengaruhi minat penggunaan produk baru (Studi kasus: uang elektronik kartu flazz BCA). Universitas Indonesia, 3.

Sitkin, S. B., \& Pablo, A. L. (1992). Reconceptualizing the determinants of risk behavior. Academy of Management Review, 17(1), 9-38.

Sjöberg, L., Moen, B.-E., \& Rundmo, T. (2004). Explaining risk perception. An evaluation of the psychometric paradigm in risk perception research. Rotunde Publikasjoner Rotunde, 84, 5576.

Suci, Y. R. (2017). Perkembangan UMKM (Usaha mikro kecil dan menengah) di Indonesia. Jurnal Ilmiah Cano Ekonomos, 6(1), 51-58. 
Tony Sitinjak, M. M. (2019). Pengaruh persepsi kebermanfaatan dan persepsi kemudahan penggunaan terhadap minat penggunaan layanan pembayaran digital Go-Pay. Jurnal Manajemen, 8(2).

Utami, R. A. (2016). Pengaruh Kualitas Sistem dan Layanan, Kepercayaan, Persepsi Manfaat, Persepsi Kemudahan dan Persepsi Risiko terhadap Sikap Penggunaan E-money. Universitas Islam Indonesia.

Venkatesh, V., \& Davis, F. D. (1996). A model of the antecedents of perceived ease of use: Development and test. Decision Sciences, 27(3), 451-481.

Wibowo, A. (2008). Kajian tentang perilaku pengguna sistem informasi dengan pendekatan technology acceptance model (TAM). Konferebsi Nasional Sistem Informasi. 